\title{
Physical activity could reduce violent behavior among undergraduate Sport Science students
}

${ }^{1}$ Ibrahim Mohammad Harafsheh \& ${ }^{2}$ Ibrahim Abdul Ghani M. Salameh\& ${ }^{3}$ Hasan alkhaldi The Hashemite University Faculty of Physical Education and Sport Science The Hashemite University

\section{ABSTRACT}

h_khaldi74@hotmail.com

The purpose of this study was to determine whether Physical activity could reduce violent behavior among undergraduate Sport Science students and may differ according to gender. The sample of study consisted of (80) male and female students of the expected graduating students in the Faculty at a rate of (\%80) from the original community. a questionnaire consisted of (10) paragraphs was used. And after doing the suitable statistical treatments it was pin-pointed that practicing the sport activities has a big role in belittling the level of violence and at a very big degree amongst students of the Faculty of Physical Education and Sport Science in the Hashemite University, and there are no differences between males and females. The researchers recommended with the necessity of preparing more studies about the phenomenon of violence for the different age stages.

\section{Indexing terms/Keywords}

Violence; Physical activity ; University students

\section{Academic Discipline And Sub-Disciplines}

Sport sciences, Sport Management, Sport sociology

\section{SUBJECT CLASSIFICATION}

Sport science

\section{Council for Innovative Research}

Peer Review Research Publishing System

\section{Journal: Journal of Social Sciences Research}

Vol. 6, No. 2

Jssreditor.cir@gmail.com

www.jssronline.com 


\section{INTRODUCTION}

Actions of violence are considered all from the most unpleasant forms of harming the security of the citizen and the community and their stability. From the clear mile stones of violence in the Twenty First Century in the spread of the sport violence phenomenon amongst the different sport quarters, in which misbehaviour and overstepping prevail made by some individuals and groups in an aggressive form, to cause anxiety cases in communities, for aggressions of all types and forms are seen as unacceptable forms of behaviour at all sport, the logical, social, and ethical levels. They decidedly seek to destroy human, educational, and noble competitive values, which the practicing of sport activities works to acquire them to individuals and groups. (Al-Mustafa, 2004)

Az-Zude \& Al-Jarrah (2012) indicate to violence as a social phenomenon refers to the beginnings of the fabulous sixties, where they included special forms of conflict of upper and lower classes in the same community. They set out of an aggressive behaviour, the individual directs it towards others, foundations, an individual and public properties all alike, either by spending cursing words, reprehending, sarcasm, or by destruction, misshaping and destroyment. And it is a pity that these forms of non-ethical behaviour become invading the sport competitions in the last period, what was known as forms of sport congregations' violence.

Many specialists in the field of psychiatry and humanities entrusted abundant concern and care about the aggressive behaviour, which produces violence for what this behaviour has of harmful extensions, and some of them are very dangerous towards the community, that is affect its functions, dislocate its structure and tear the tissue of its unity (lisa; Layekh, 2009).

And zreigat (2006) defines violence that it is irritation of evil or disorder among the group, that is by causing damage to others, or by spreading corruption or stirring disorder and attracting others, to collision and fighting, for example he meant with violence in the sport playgrounds the aggressive action; beating, burning, destruction and damaging, and also the unproper and non-ethical behaviour, done by players, administrators, and sport congregations, violating systems and civil laws valid before, during, and after sport-competitions.

And Aa-Lawi (1998) explains the violence phenomenon due to the factor of emptying the suppressed emotions amongst supporters of instincts theory or the theory of release, for the noticed thing is that the aggressive behaviour and violence may increase or decrease after the termination of some football matches, and the factors and causes that lead to violence can be confined to characteristics of competitions, traits of the public, or the environmental factors, such as the influence of media means, education factors, problems concerning individuals vanity or weakness of security perfection and the local or national conflicts.

Sport is one of the most important spheres in life, that lead to violence amongst individuals. Some of them view that it is a means of release about the suppressed aggression in the human soul. Others view that it shares in creating aggressive communities through circumstances of deprivation left by repeated frustration. And also through the restrictions forced by the sport laws (lisa; Layekh, 2009).

And the World Health Organization defines violence as the excessive usage of materialistic power, or capacity by threatening or actual using of it by the person or against himself or against another person or against group or community, where there is a possibility of occurring casualty and death, or a psychological casualty or drop of growth or deprivation (World Health Organization, 2005).

Violence has three types, they are:

Violence towards a person himself including suicide and self-violence.

Violence among persons, divided into:

a. Family violence, and among mates, tightly related this usually occurs in the house, but not absolutely, such as childrenviolation, tightly-related mates violence, and old men violation.

b. Societal violence: it is the violence that happens among unrelated individuals, and they may know each other, or may not and happens outside the house, such as bands violence and random actions of violence or rape by strangers and violence in institutions as schools and universities and places of labour and jails.

c. Economic violence: it covers the attacks of the biggest groups with drives of economic earnings, like the attacks which are carried out aiming at breaking down the economic activities and breaking down achieving the basic services, or spreading divisions or economic partition.

Group violence, which is divided into two divisions represented in the social violence that shows hatred crimes by organized groups and the terrorist actions and violence of criminal gangs, and political violence which in dudes the war battles and violence related to them. (World Health Organization, 2005).

And Al-Hawamdeh (2007) considers violence in the universities one of the negative phenomena, that hinder achieving their objectives, that is because universities are doing a basic role in building the personality of the student, for it seeks to originate a peaceful environment to dedicate students deepened scientific study. And the Jordanian Universities witnessed, in the last period, a battle field of fighting, in which the student aggresses against his colleague, and the matter reached with some students to practice direct aggression against some professors, and stabbing them or attempting to stab, or using forearms against a professor in the campus. Examples are well known in our Jordanian community and in some Arab brother states, and if this phenomenon became serious, the university system will transform into a law of a 
jungle where the university will lose its classical functions in preparing and constructing the human, to be beneficial to his community.

And many theories attempted explaining the violence phenomenon at different forms, from these theories:

Theory of Biological Explanation:

This theory views that there is a relationship between violence and the different circumstances of genetic and harmonic installations, where experts uncovered that the forefront area and the terminal system are responsible for the aggressive behaviour at the human being, and also many biological studies proclaimed the increase of males aggressiveness compared with the females'. Part of that refers to existence of a relationship between the hormone of manhood and aggression, in addition to that (pressure, frustration, and fear) have a great effect on the excretions of hormones which affect the behaviour like ixrotoneen hormone, that decreases with pressure (Eron, 2005).

Theory of Environmental Explanation:

These theories grant a big role to the effect of the environment in violence appearance, of them:

Frustration Theory: it indicates that frustration is always producing an aggressive against drive others, and this drive decreases gradually after causing damage to the other person, and this operation is called breathing or emptying.

Theory of Behaviour: this theory views that this behaviour and aggression are learnt behaviour. For if the boy hits his brother and gets what he wants from him, he will repeat his behaviour so that he achieves a new objective (Yahya, 2000).

Social Theory: this theory views that violence and aggression behaviour are being learnt through learning by the direct experience and through noticing the family aggressive models, and models of mates, or the models shown by media means, like the television (Yahya, 2005).

Theory of Aiming at Violence: this theory views that there is the person who looks at someone else from the people as if they were machines, tools, or wooden toys that do not feel and were made particularly to fulfill his needs and purposes, and it has no right in life and can do to it whatever he wants. And there is the person who feels that he is exposed to attack, because he is not fortified, and such person is with extreme sensitivity for criticism, and he is swiftly affected by criticism and seduction (Al-lisawi, 2000).

And Ni'mah (2011) indicates that practicing physical activities share in originating physiological changes that may be reflected on individuals' behaviour in a positive from.

And Al-Hawamdeh (2007) inspires in his study "Students violence in the formal and private Jordanian Universities" to increase the different student activities and from them sports and supporting them to fill leisure times and release for concealed energies, which work to decrease the phenomenon of violence.

Practicing sport activities in general shares in improving the social, physical mental and psychological sides, and so reaching a state of integration at the human, for seeking to stuff the needs at the human, even by the few we can let him reach a state of consent and conviction in life. Thereupon, he has to exploit and release the concealed energies at him, that the physical activities, the codified and controlled by rules and systems of playing, from part of changing the mistaken behaviour at the practitioner individuals at a very big form, especially those forms of behaviour that lead to violence of all its shapes. So, subduing the individual to similar stands to life during playing, especially those stands which bear aggressiveness and violence against the rival and the capacity of the individual to control himself during it, and his commitment, with the rules of playing for fear of punishment, make behaviour that lead to violence are rejected, through a state of generation of self-control. Due to what has been preceded the significance of this study comes to prove that sport physical activities share in decreasing states of societal violence, and so the sharing of this study results in submitting sport programs, with competitive nature, to administrations of Jordanian universities to urge students to practicing physical activities, and submitting the necessary support for physical activities to merge the greatest number of university students in the different sport activities.

\subsection{Research Problem:}

Many studies had indicated to the effect caused by practicing the physical activities on changing the individuals' behaviour towards going far away from aggressiveness that leads to violence with its different appearance, but there are some studies that indicated to many appearances of violence amongst some athletes. But what researchers view that appearances of violence in Jordanian Universities, most of them exist in many community colleges, at the level of Faculties of Physical Education in the Jordanian Universities, the level of violence is very low, and can be non-existing, thus the problem of study was generated to prove that violence amongst students of Faculties of Physical Education is low, because of practicing the physical activities, either at the methodological or un-methodological level, and so causing physical physiological changes amongst individuals may change some biological characteristics. And so causing these changes will do the best to change the behaviour that leads to occurrence of violence.

Niimeh \& Shabeeb (2011) found that physical education lesson in some physiological variables can decrease violence phenomenon.

Bani Khaled et. al., (2003) indicate in his study the scholastic violence has numerous forms, of them the indirect, sentimental, and bodily violence. And the operation of decreasing it is a complicated one, needs comprehensive programs and general for all parties of the educational operation. 
But the study of Bin Dureidi (2007) which was done in Algeria had aimed at specifying the size of violence phenomenon spread amongst the pupils of the secondary stage, and specifying the sociological factors leading to the pupils' violence, and the sample of study amounted to (180) pupils, and the instruments of study were the notice, meeting, and three models of the form: a model for the pupils, a model for the teachers, and a model for the administration. And the researcher did process the data by using a middle method between the quantitative track and the qualitative one in analysis. The study deduced that violence is clearly spread in the Algerian Secondary Schools, and violence refers to a group of factors, of them are: poverty, the difficult economic condition, cultural and educational weakness of people in charge of pupils, learning the culture of the quarter, and violence used by the family towards its sons. Furthermore, study done by Mamser (1989), aimed at analyzing the phenomenon of sport riots in the playgrounds of the Arab World. The study had been applied on a sample consisted of (3002) individuals of experts, players, trainers, administrators, media experts and referees from Jordan, Syria, Lebanon, Palestine, Iraq, Egypt, Lybia, Algeria, Tunisia, Saudi, Kuwait, Emirates, and Qatar. And results had indicated that elements of riots are eight, the public and players, referees, administrators of the sport unions, experts of sport media, and trainers, and finally policemen and first aid men physicians. And appearances of players and crowds riots are represented in un-proper behaviour, non-ethical behaviour as actions of violence and aggression. But stealing instruments of the playground and infiltration into the playground, like firing. It came in the last ranks from part of its generalization by sport crowds. The study results also assured that from the most prominent appearances of administrators of sport clubs riots are concized in provocation of crowds and doubting in fairness of arbitration. But appearances of trainers' riots were represented in the repeated objection against referees decisions and descending into the playground, and articulating with canine words. And finally, results cleared that causes of sport riots can be confined in the four levels: madness of sport competition, improving the competitive sport, social nurturing, and the negative personal traits.

Researchers indicated that young adults, as a group, were more likely to hold negative attitudes toward

the use of physical violence than other groups (Cate et al., 1982; Henton et al., 1983)

Ramzy (2007) prepared a study, aimed at reconnoitering the sport violence in the Palestinian playgrounds and its causes where the study was done on a sample of (152) persons. And the study showed that causes of the sport violence in the Palestinian playgrounds are resulting from non-existence of a system for protecting the referees in the first place, and in the second place results showed existence of crowd awareness, but in the third place the cause was non-existence of deterring punishments against dissenters.

Abu Haleemeh (1995) did a study, aimed at reconnoitering appearances of sport riots in playgrounds of hand-ball, and their causes through a questionnaire, distributed on a random sample, consisted of (450) individuals, covered players and crowds, referees, and administrators in the Jordanian sport tournament. And the results had cleared that appearances of sport riots were represented in the weakness of the sport awareness sport at the public, weakness of arbitration level, and also losing trust between the rules and following what newly develops of information. The results also indicated that is clear crowd fanaticism to the different sport teams, in addition to the weakness of the technical level of players, and carelessness in the deterring procedures of the crowd and players, the thing that excites the sport riots.

\subsection{Study aims:}

Objectives of Study were to determine whether Physical activity could reduce violent behavior among undergraduate Sport Science students and may differ according to gender at the Hashemite University .

\subsection{Study Questions:}

Does the practice of sport activities by students of the Faculty of Physical Education and Sport Science work to decrease the violence level?

Are there differences with statistical indication at the level of $(0,05=>a)$ in the decrease of violence level by means of practicing sport activities in the Faculty of Physical Education and Sport Science in the Hashemite University due to variable of sex?

\section{MATERIALS AND METHODS:}

\subsection{Participants and Procedure}

the sample of study consisted of (80) students from the Faculty of Physical Education and Sport Science in the Hashemite University, expected to graduate in the university year (2014-2015) for they were chosen at a random method at a rate of $80 \%$ from the original community, and their ages amounted between (22-23) years.

\subsection{Instrument}

The instrument of study was designed by researchers and shown on a group of arbitrators specialized in humanities in the Hashemite University. And the questionnaire was shown to these arbitrators to give their opinion in the extent of validity of each paragraph, and the extent of its belonging to the dimension under which it is enlisted, and the extent of its formation appropriation, and then the paragraphs unanimously agreed by members of arbitration committee, and appendix No. 1 illustrates that.

Assurance of the validity of the instrument (the questionnaire). The validity of instrument was assured by showing it to three of arbitrators with experience to have their views. 
Reliability of Instrument:

Reliability of study instrument was assured through using the method (Test \& retest), That is by applying the instrument of study on an exploratory sample consisted of (20) male and female students from the Faculty of Physical Education and Sport Science in the Hashemite University. And the reapplying the instrument of study on the same sample after a week of applying to the first time, then counting the Pearson's connecting coefficient between the instrument of this sample in the two periods of application, and at counting the reliability coefficient it was pin-pointed that it registered $(0,85)$ and the coefficient is statistically acceptable, the thing that made the instrument fit for the purposes of study.

The researchers distributed the questionnaires among the students inside one of the university halls and asked them to read the questionnaire well, and then answer faithfully the paragraphs of it within half an hour. For the questionnaire included one dimension, it is violence inside the university and within the classrooms, and appendix (2) illustrates that.

researchers collected the questionnaire and assured that all students had answered it.

researchers used leakart's fivefold scale in answering the paragraphs of the questionnaire as follows:

At a very few degree, (2) at a few degree (3) at a medium degree, (4) At a big degree (5) at a very big degree.

For he used the statistical model with absolute graduation as follows:

$(1-1,79)$ at a very few degree.

$(1,80-2,59)$ at a few degree.

$(2,60-3,39)$ at a medium degree.

$(3,40-4,19)$ at a big degree.

$(4,20-5)$ at a very big degree.

researchers after it did the statistical processing that serves the objective of study.

researchers to answer the inquiry of study used the arithmetic means and standard deviations, percentage rates and test of one way analysis (ANOVA).

\section{RESULTS}

To answer the inquiry of study that words "does practicing sport activities by students of the Faculty of Physical Education and Sport Science in the Hashemite University work to decrease the level of violence?" researchers used arithmetic means and standard deviations, and percentage rates, and the table No.(1) \& (2) illustrate that.

Table . 1 Means and standard deviations, and parentage rates concerning the practice of sports activities and decrease of violence level amongst students of the Faculty of Physical Education and Sport Science, the males in the Hashemite University.

\begin{tabular}{|c|c|c|c|c|c|c|}
\hline Rank & $\begin{array}{c}\text { Parag } \\
\text { No. }\end{array}$ & Paragraph & No & $\begin{array}{c}\text { Arithmetic } \\
\text { Means }\end{array}$ & $\begin{array}{c}\text { Standard } \\
\text { Deviations }\end{array}$ & $\begin{array}{c}\text { Percentag } \\
\text { e Rates }\end{array}$ \\
\hline 1 & 6 & $\begin{array}{c}\text { I do not damage the properties } \\
\text { of the university }\end{array}$ & 40 & 4,34 & 6,50 & 86,80 \\
\hline 2 & 3 & $\begin{array}{r}\text { I do not insult my colleagues } \\
\text { or degrade them }\end{array}$ & 40 & 4,34 & 2,50 & 86,80 \\
\hline 3 & 5 & $\begin{array}{c}\text { I do not use technique of } \\
\text { provocation to hinder teaching }\end{array}$ & 40 & 4,33 & 5,90 & 86,60 \\
\hline 5 & 8 & $\begin{array}{r}\text { I do not criticize my group } \\
\text { professors continuously }\end{array}$ & 40 & 4,32 & 9,50 & 86,40 \\
\hline 6 & 9 & $\begin{array}{c}\text { I do not bring or carry with me } \\
\text { sharp tools to any place } \\
\text { lectures playing with the } \\
\text { mobile or drawing on the copy } \\
\text { book }\end{array}$ & 40 & 4,28 & 6,60 & 85,60 \\
\hline 7 & 1 & $\begin{array}{c}\text { I do not ridicule or mock at my } \\
\text { colleagues at any way }\end{array}$ & 40 & 4,25 & 0,430 & 85,00 \\
\hline
\end{tabular}




\begin{tabular}{|c|c|c|c|c|c|c|}
\hline 9 & 10 & $\begin{array}{c}\text { I do not be angry when } \\
\text { discuss with my colleagues }\end{array}$ & 40 & 4,22 & 0,410 & 84,40 \\
\hline 10 & 2 & $\begin{array}{c}\text { I do not do any suggestive } \\
\text { movement, harmful to my } \\
\text { colleagues }\end{array}$ & 40 & 4,21 & 0,360 & 84,29 \\
\hline
\end{tabular}

It is clear from table No. (1) in what concerns the objective of study, and decrease of violence level caused by practice of students of the Faculty of Physical Education and Sport Science, the males in the Hashemite University that all paragraphs got a big degree, that their arithmetic means amounted $(4,21-4,34)$ and percentage rates $(84,29-86,80)$, where the paragraph No.(6), that words " I do not damage the properties of the university" got the first rank at an arithmetic mean $(4,34)$ and a percentage rate $(86,80)$ meanwhile the paragraph No.(2) that words" I do not do any suggestive movement, harmful to my colleagues" got the last rank, at an arithmetic mean $(4,21)$ and a percentage rate $(84,29)$.

Table No. (2) Means and standard deviations and percentage rates concerning sport activities and decreasing the level of violence amongst female students of the Faculty of Physical Education and Sport Science in the Hashemite University

\begin{tabular}{|c|c|c|c|c|c|c|}
\hline Rank & $\begin{array}{l}\text { Parag, } \\
\text { No. }\end{array}$ & Paragraph & No & $\begin{array}{l}\text { Arithmetic } \\
\text { Means }\end{array}$ & $\begin{array}{l}\text { Standard } \\
\text { Deviations }\end{array}$ & $\begin{array}{l}\text { Percentage } \\
\text { Rates }\end{array}$ \\
\hline 1 & 3 & $\begin{array}{l}\text { I do not insult my colleagues or degrade } \\
\text { them }\end{array}$ & 40 & 4,34 & 2,65 & 86,81 \\
\hline 2 & 1 & $\begin{array}{c}\text { I do not mock at my colleagues or joke } \\
\text { them anyway }\end{array}$ & 40 & 4,34 & 2,60 & 86,80 \\
\hline 3 & 10 & $\begin{array}{l}\text { I do not show anger when I negotiate my } \\
\text { colleagues }\end{array}$ & 40 & 4,33 & 4,80 & 86,60 \\
\hline 4 & 9 & $\begin{array}{l}\text { I do not make trouble outside the lecture } \\
\text { classroom }\end{array}$ & 40 & 4,31 & 6,50 & 86,40 \\
\hline 5 & 7 & $\begin{array}{l}\text { I use the language of dialogue with my } \\
\text { colleagues instead of violence }\end{array}$ & 40 & 4,30 & 2,50 & 85,39 \\
\hline 6 & 6 & $\begin{array}{l}\text { I do not damage the properties of the } \\
\text { university }\end{array}$ & 40 & 4,28 & 6,60 & 85,30 \\
\hline 7 & 7 & I do not continuously criticize a professor & 40 & 4,26 & 6,40 & 85,20 \\
\hline 8 & 2 & $\begin{array}{l}\text { That I do not make any suggestive } \\
\text { movement harms my colleagues }\end{array}$ & 40 & 4,25 & 4,30 & 84,10 \\
\hline 9 & 5 & $\begin{array}{c}\text { I do not use the technique of provocation } \\
\text { to hinder teaching operation }\end{array}$ & 40 & 4,23 & 4,21 & 84 \\
\hline 10 & 8 & $\begin{array}{c}\text { I do not carry sharp tools with me } \\
\text { anywhere }\end{array}$ & 40 & 4,22 & 4,10 & 83,90 \\
\hline
\end{tabular}

It is clear from table No,(2) and what concerns the objective of study and decrease the level of violence, caused by the practice of female students of the Faculty of Physical Education and Sport Science in the Hashemite University that all paragraph got a big degree, and their arithmetic means amounted between $(4,22-4,34)$ and percentage rates (83,9086,81 ) for the paragraph No.(3), that words" I do not insult my colleagues or degrade them" got the first rank, at an arithmetic mean of $(3,34)$ and a percentage rate of $(86,81)$ mean, while the paragraph No. $(8)$ That words "I do not carry keen tools with me anywhere" got the last rank and at arithmetic mean of $(4,22)$ and a percentage rate of $(83,90)$.

To answer the second inquiry, that words "Are there differences with statistical indication at the level of $(0,05=>a)$ in the decrease of violence level caused by practicing sport activities in the Faculty of Physical Education and sport Science in the Hashemite University, due to the variable of sex"? And table No. (3) illustrates that.

Table No. (3) The means and standard deviations concerning the field of study, and it is the decrease of violence level, caused by practicing sport activities due to the variable of sex,

\begin{tabular}{|c|c|c|c|c|}
\hline Field of study & $\begin{array}{l}\text { Independent } \\
\text { Variable }\end{array}$ & $\begin{array}{l}\text { Level of Independent } \\
\text { Variable }\end{array}$ & Arithmetic Mean & $\begin{array}{c}\text { Standard } \\
\text { Deviations }\end{array}$ \\
\hline $\begin{array}{c}\text { Decreases } \\
\text { of Violence Level }\end{array}$ & Sex & Males & 4,300 & 0,104 \\
\hline $\begin{array}{c}\text { Decreases } \\
\text { of Violence Level }\end{array}$ & Sex & Females & 4,290 & 0,088 \\
\hline
\end{tabular}


Table No.(3) shows clear differences in the arithmetic means concerning the field of study, and it is the decrease of violence level and the scale as a whole due to the independent variable of study, and to specify if these differences were with statistical indication, The one way analysis test (ANOVA) was used and the table No.(4) illustrates that.

Table.(4) It illustrates the results of analyzing the one way (ANOVA) of the variable of study (sex) on the field of study concerning the decrease of violence level, caused by practicing sport activities.

\begin{tabular}{|c|c|c|c|c|c|c|}
\hline $\begin{array}{c}\text { Variable of } \\
\text { study }\end{array}$ & $\begin{array}{c}\text { Total of } \\
\text { Squares }\end{array}$ & $\begin{array}{c}\text { Degree of } \\
\text { Freedom }\end{array}$ & $\begin{array}{c}\text { Squares } \\
\text { Average }\end{array}$ & F. Value & $\begin{array}{c}\text { Truthful, Level of } \\
\text { Indication }\end{array}$ & Indication \\
\hline $\begin{array}{c}\text { Drop of } \\
\text { violence } \\
\text { Level }\end{array}$ & 0,008 & 1 & 0,008 & 0,040 & 0,860 & $* * * * *$ \\
\hline
\end{tabular}

It is clear from table No.(4) the non- existence of differences with statistical indication on the field of study, and it is the decrease of violence level, caused by practicing sport activities, due to the variable of sex, for the level of indication amounted to $(0,841)$ and it is not statistically indicative.

\section{DISCUSSION}

researchers will deal with the discussion of study inquiry, which words "Does practicing sport activities by students of the Faculty of Physical Education and Sport Science in the Hashemite University work to decrease the level of violence?"

It is clear from results the decrease of violence level among students of the Faculty of Physical Education and Sport Science in the Hashemite University, caused by practicing the sport activities and at a very big degree, and table (1) \& (2) both illustrate that, and the two researchers ascribe that sports are an educational operation affecting the individuals behavior, where concealed energies and additional emotions come out during the practice of activity, in addition to that numerous researches indicated to the existence of Physiological changes organize the action of some hormones in the body, and responsible for additional emotions, such as ( the adrenaline \& noradrenalin), and also sport shares in preoccupying leisure times amongst students; they have no enough time to direct friction with student of the University, but among them the social relations increase, and this necessarily leads to treating very well among themselves.

But the Second Variable:

"Are there differences with statistical indication at the level of $(0,05=>a)$ in the decrease of violence level, caused by practicing the sport activities in the Faculty of Physical Education and Sport Science in the Hashemite University, due to the Variable of sex?"

There were no differences between males and females for the decrease of the level of violence, and the two researchers ascribe that to that the stage of university study is a stage of building the personality and directing positively the behavior, so through the sport activities relations increase among students, especially among the females, where the stage after maturity amongst females is described as a stage of building passion and the traits of personality and so merging them both customs and traditions in the community, for the female cannot behave violently, because this harms her reputation as it is known in our Arab communities, in addition to physiological changes that occur in the human body in this period.

But due to males the two researchers view that the social relation increases among them, for sport works to uproot anger during practicing it and subdues the individual to similar stands in life, for example: if the individual was exposed to a certain problem outside the range of sport activities, he may be exposed to a similar stand during the practice of sport activities, he can uproot his anger and perceive that there are rules and systems that control his behavior and direct him to control oneself.

\section{CONCLUSION}

Practicing sport activities shared in decreasing the level of violence amongst students of the Faculty of Physical Education and sport Science in the Hashemite University. There are no differences between males and females, caused by practicing sport activities in decreasing the level of violence. The researchers recommend that Doing more studies relating to the effect of practicing sport activities on different age classes.Submitting the results of the study to the Ministry of Higher Education to urge presidents of universities, and officials in the universities to direct students towards practicing the sport activities to decrease the level of violence, being the phenomenon of university violence spread a great deal in the community.

\section{References}

1. Aalawi, Mohammad, (1998). Aggression and Violence Psychology in Sports. Book center for Publication, Egypt.

2. Abu Haleemeh, khalifah Taleb (1995)". Appearances of playgrounds riots in the handball and its causes from the point of view of the Jordanians, players, and the public". Dirasat Journal for Humanities, (5). University of Jordan.

3. Al-Hawamdeh, Kamal,(2007). Students Violence in the Jordanian Universities, formal and Private, from the point of view of students in them, Journal of Humanities, (12). Mohammad Khdeir Biskert, Algeria, 
4. Al-Isawi, Abdel Rahman. (2000). Disorders of Childhood and Adolescence and their Treatment. University Dar Arateb, Beirut, Lebanon.

5. Al-Mustafa, Abdel Aziz, Abdel Kareem. (2004). Sport Playgrounds Riots; Incentives \& Types. Nayef Arab University for Security Sciences. Saudi Arab Kingdom.

6. Az-Zude, Khaled, Al-Jarrah, Maamoun. (2012). Sport Violence in the Jordanian Football Playgrounds, Journal of An-Najah University for Humanities, 26(6) Palestine.

7. Bani Khaled, Mohammad Suleiman et. al., (2008). Reality of Scholastic Violence in the Secondary Education Stage in Jordan: a State Study. A published research in an Electronic Journal For Humanities, A Refereed Periodical Journal concerned with humanities, No. (44). Site: www,ULUM,NT

8. Bin Duraidi, Fawzi Ahmad. (2007). Violence amongst pupils at Algerian schools, Center for Researches and studies, Nayef Arab University for Security Sciences, Riyadh, Saudi Arab Kingdom.

9. Cate, R., Henton, J., Koval, J., Christopher, S., and Lloyd, S. (1982).Premarital abuse: A social psychological perspective.J. Fam. Issues 3: 79-90

10. Henton, J., Cate, R., Koval, R., Lloyd, S., and Christopher, S. (1983). Romance and violence in dating relationships.J. Fam. Issues 4:467-482

11. lisa, Ghaffar \& Layekh, Khaled. (2009). Aggressive Behavior amongst Athletes and Non-Athletes. Waset Journal for Humanities. (12).

12. Mamser, Mohammad. (1989). Sport Playgrounds Riots, The Sixth Asian Symposium for Sport Journalism, The Jordanian Union for Sport announcement and Youth in Cooperation with the Asian Union for Journalism, Jordan.

13. Niimah, Iqbal \& shabib, Huda. (2011), Effect of a Suggested Program to Physical Education Teaching in some Physiological Variables and Decreasing the Phenomenon of Scholastic Violence, The Periodical Conference, the 18th, For Faculties of Physical Education in Iraq. Iraq.

14. Ramzi, Jaber, (2007). "Sport Violence in the Palestinian Playgrounds", Journal of Islamic University, Series of Human Studies (2). Al-Aqsa University. Palestine. 1109-1132.

15. World Health Organization (WHO).(2005). Health and Violence. The National Council for the Family Affairs. Edited by Munzer Arafat Zayton. The Hashemite Kingdom of Jordan.

16. Yahya, Khawlah. (2003). Psychological and Emotional Disorders, 2nd ed. Darel Fiker for Publication, Jordan.

17. Zuriagat, Murad, (H1427). Crime of Playgrounds Riots, Nayef Arab University for Security Sciences. Faculty of Postgraduate Studies. Saudi Arab Kingdom. 